\title{
NOTAS
}

\section{Rómulo Gallegos}

La muerte de Rómulo Gallegos habrá hecho pensar a muchos en que es hora de hacer una revaluación de su obra, una revaluación crítica, a la luz de las cargas y descargas que se disparan hoy en la vanguardia de la novelística latinoamericana. Imagen (No 46, Caracas, abril 1969) recomendó a sus lectores rendir un homenaje a Gallegos en forma de una lectura creativa de sus cuentos y novelas, es decir, componiendo a su sombra el lugar histórico en que fueron escritos y proyectándolos sobre las circunstancias actuales.

La pregunta que se hará este lector crítico no será tanto ¿qué ha quedado y qué va a quedar de Gallegos? sino: ¿por qué se empeñan tantos en arrinconarlo en una época poniéndole cercos impasables, subiéndolo ya al pedestal de un monumento donde sus libros se habrían hecho piedra?

Gallegos podría sorprender a sus enterradores. Así como sorprenden también Azuela y Güiraldes. En estos días de laberintos, paradisos y rayuelas, uno piensa con cierta nostalgia en esos años en que la novela latinoamericana se dividía en "novelas de la tierra y novelas de la ciudad", en que el duelo se daba a muerte entre la naturaleza y el hombre, y la selva era una verdadera amazona, cazadora de Arturos y Montieles. Se encasillaba a los escritores con intención dogmática y arrogante finalidad. Se leía Doña Bárbara, Los de abajo, La vorágine y Don Segundo Sombra. Punto. Esta es la novela hispanoamericana, se decía, ipobre del crítico, del profesor o del estudiante que buscara un hueco para Barrios, Lynch o Artl en esa edad frondosa del super-regionalismo de los años 20 y 30 !

Los sostenedores de ese boom (que, en verdad, no era todavía un autoboom) cometían, es claro, un pecado mortal: de antemano condenaban a muerte a sus campeones. Porque pasó la era estrictamente geográ- 
fica y nacionalista de nuestra novela y el regionalismo se desplomó como un viejo decorado de ópera y de las noches de gala no quedó sino un polvo denso y picante en el aire, ruido de cosas que seguían cayendo $y$, después, un escenario vacío, en ruinas, y vino la transición difícil de que hablan los jubilados, una especie de momento de la verdad al revés, cuando ya no se arriesga nada porque o todo se ganó o se perdió todo y los maestros se miraron las caras y algunos libros dejaron de leerse, y codeándose aparecieron los que venían pisándoles los talones, y se produjo un reagrupamiento en las filas y ciertas voces modestas, hasta entonces, empezaron a sonar con autoridad. Es el destino de los booms, se dirá, cada boom lleva su antiboom en su vejiga, y hasta el más intrincado, programado y computarizado de los booms, tiene su agujerito por donde se le saldrá el aire.

Lo curioso, tal vez por inesperado, es que si algunos cayeron en el fragor de la batalla, otros se salvaron y han sobrevivido fortificados. Azuela es uno, Güiraldes es otro, y Gallegos un tercero.

Para algunos Gallegos se salvó porque escribió como Neruda cuando decía: "Dios me libre de inventar nada". Era su propósito proclamar un testimonio honrado y directo, pero preñado de símbolos, de la condićión social de su pueblo. Digo proclamar porque hay en Gallegos --el luchador social- una elocuencia, que carga sus diálogos y hasta descripciones más objetivas, dirigida a un lector-alumno, ser en proceso de liberarse que siempre aprenderá algo en sus novelas. Lecciones de folklore, de solidaridad humana, de psicología de las pasiones, de oficios y profesiones, de historia patria, de vida del campo y de la ciudad, de revoluciones y de idilios: Gallegos era un maestro con la pluma en la mano, un vidente de horizonte amplio, de memoria minuciosa, de largo aliento, un realista tocado por emociones básicas, primitivas, ante el paisaje y un romántico para considerar la desesperanza, la soledad, el estoicismo del hombre que él conocía.

Hay una foto de Rómulo Gallegos en el número de Imagen ya citado que lo muestra regalándole sus libros a Faulkner en Caracas. Es una foto extraña $y$, hasta cierto punto, patética. Gallegos parece pasarle a Faulkner algo que en sus manos es como una vida hecha papel. Faulkner no sabe qué hacer con eso. No lo sabría nunca. Gallegos podía entregar asii, materialmente, realísticamente, su mundo. Faulkner habia inventado el suyo y nơ podía dárselo a Gallegos con la misma facilidad, le habría llevado mucho tiempo el recogerlo en sus manos y pasárselo al otro sin que se le derramara entre los dedos. 
Gallegos sabía que su mundo funcionaba de acuerdo a ciertas reglas establecidas, bajo las cuales era posible ordenar una visión dialéctica y darle forma artística a sus oposiciones y símbolos: idealistas fallidos, trepadoras triunfantes, muerte y sexo, civilización y barbarie, caudillismo y conciencia social. Estas son las categorías en que Gallegos reparte la suerte del hombre hispanoamericano de este siglo. Le ha visto levantarse y caer, liberarse y someterse a la dictadura, enfrentarse a sus explotadores y claudicar, cercar el monte y perderse en un cataclismo.

Desde un comienzo Gallegos escribe como un anciano patriarca que rememora y revisa las relaciones de la familia y saca sus conclusiones y sus moralejas. Sus novelas, Reinaldo Solar, La Trepadora, Pobre negro, Doña Bárbara, Canaima, Sobre la misma tierra, La brizna de paja en el viento, lucen la armazón del costumbrismo clásico; se sostienen en un lenguaje castizo de América donde nada sobra ni nada falta; tienen la rigidez de una sinfonía y su misma resonancia y poder de ensueño.

Después de Gallegos, otros han escrito sobre la barbarie, la desigualdad social y los odios raciales, sobre el petróleo, el contrabandismo, el caudillismo, los estudiantes, los dictadores, sobre esta selva u otra, montañas, valles, llanos y ciudades de América. Para perder de vista al maestro han barajado libremente su naipe: transformando la narración en film, como se dice hoy, disolviendo las unidades del tiempo y las personas verbales, estructurando, construyendo, parchando, oscureciendo, para proyectarse un tanto a la suerte en un mundo que aprecia la noción de un caos creador.

Rómulo Gallegos les echa sombra. Y es una sombra que no puede borrarse. Va con el tiempo, es el tiempo, el verdadero, el único que tenemos, que nos mide hoy y seguirá midiéndonos.

Fernando Alegría

Stanford University 
